\title{
The Effects of Fiscal Policy Shocks in Morocco: An SVAR Approach
}

\author{
Firdawss Tahri ${ }^{1} \&$ Mohamed Karim ${ }^{1}$ \\ ${ }^{1}$ EREMEPP, University of Mohammed V, Rabat, Morocco \\ Correspondence: Mohamed Karim, Mohammed V University, Rabat, Morocco.
}

Received: November 9, 2017

Accepted: February 6, $2018 \quad$ Available online: February 22, 2018

doi:10.11114/aef.v5i2.3406

URL: https://doi.org/10.11114/aef.v5i2.3406

\begin{abstract}
Interest in assessing the effects of fiscal policy shocks on macroeconomic variables, especially on GDP, has surged in recent years, since it was expected to reestablish the economic balance after the recent recession. The majority of empirical studies estimate the impact of fiscal policy on economic activity using vector autoregressive (VAR) models. This paper analyzes the effect of fiscal shocks on economic activity by applying the structural VAR methodology proposed by Blanchard and Perotty (2002) to Moroccan data. The empirical findings are consistent with other studies related to emerging economies. This assessment reveals a positive impact of expansionary fiscal policy on economic activity. However, the fiscal multipliers are found to be very small, meaning that the economic activity is not significantly influenced by fiscal policy shocks.
\end{abstract}

Keywords: fiscal policy shocks, SVAR modeling, impulse response function

\section{Introduction}

The recent global economic and financial crisis has revived the interest in understanding the fiscal policy impact in advanced and developing economies. For a developing country like Morocco, the importance of the impact of fiscal policy lies on its potential benefits for stabilizing the economic cycle and stimulating economic activity during a recession.

A shock programmed by public authorities on taxes or spending is supposed to have a positive effect on the budget deficit, contributing to a more balanced macroeconomic stability and growth. In fact, the government can use fiscal policy as stimulus to the economy by adjusting revenue and spending. Public spending is used to guide government resources to boost certain sectors. As with taxes, they can be used to cover public spending or/and to guide spending of agents to certain sectors in order to achieve economic and social objectives. The changes in the level and composition of taxation and government spending can affect the level of economic activity.

The debate on efficiency of fiscal policy has been launched by Blanchard and Perotti (2002), who did an assessment of its dynamic effects on the macroeconomic variables, the Gross Domestic Product (GDP) in particular, using a structural Vector Autoregressive (VAR) model. This paper is inspired by this methodology to assess the effectiveness of fiscal policy in Morocco. The results are consistent with the economic theory, however, the fiscal multipliers are very small and the responses are less persistent.

The remainder of this paper is organized as follows: Section 2 presents the literature review. Section 3 presents the different empirical approaches used to identify fiscal policy shocks. Section 4 includes a description of the Blanchard and Perotti approach. Section 5 discusses the effects of fiscal policy on macroeconomic variables and Section 6 concludes.

\section{Review of Theoretical Literature}

Governments typically use fiscal policy to influence the level of aggregate demand in the economy, in order to achieve economic objectives of price stability, full employment, and economic growth. The Keynesian theory states that increasing government spending and/or decreasing taxes in times of recession, restore economic growth and generate full employment. However, it can also increase inflation. On the other hand, lowering public spending and/or an increasing in taxes may reduce inflation. But, it can also cause some unemployment.

The multiplier effect of fiscal policy was criticized by neoclassical economist, which highlights the neutral effects of fiscal expansion due to the effects of wealth and inter-temporal substitution. According to the hypothesis of Ricardian 
equivalence, if fiscal expansion is financed by debt, the public anticipate a future tax increase and react by saving its excess money. Therefore, the government cannot stimulate the economic activity, because no matter how it chooses to finance its spending, by debt or taxes, the demand remains unchanged.

Mundell-Fleming model enriches the analysis of the effectiveness of fiscal policy by generalizing the IS - LM model to an open economy. The model suggests that the effect of fiscal shocks depends also on the exchange rate regime and the capital mobility. It shows that fiscal policy is ineffective in a flexible exchange rate regime and perfect capital mobility, as an increase in public spending reduces the demand for domestic products due to the appreciation of the exchange rate. Also, in a situation of fixed exchange rates and a lack of mobility of capital, fiscal policy has no effect on real activity. In fact, when a country increases its spending, the expansion of imported products generates a need for currency, which causes a depreciation of the exchange rate. As a result, the Central Bank intervenes to support the national currency by contracting the money supply and raising the interest rates.

\section{Review of the Empirical Literature}

The empirical studies using VAR model have different approaches to identify fiscal policy shocks. The four main identification approaches are: the recursive approach introduced by Sims (1980), the narrative approach proposed by Ramey and Shapiro (1998), the structural vector autoregressive (SVAR) approach developed by Blanchard and Perotti (2002) and the sign-restrictions approach used by Uhlig (2005). All identification approaches used in the literature yield to very similar results as regards the effects of government spending shocks (Caldara and Kamps, 2008). A Bayesian VAR method is also used to estimate the effect of a fiscal policy intervention on macroeconomic variables. Furthermore, complex studies using dynamic stochastic general equilibrium (DSGE) models have been developed recently to quantify the effects of fiscal policy.

The narrative approach of Ramey and Shapiro (1998) is based on a historical method to identify the changes in the tax legislation through successive finance laws. Once these shocks are identified, their effects will be estimated in a dynamic model. By adopting this method Romer and Romer (2007) have tried to examine the impact of tax changes on economic activity in the United States. Their analyses point out that there are three types of variations, those that are related to legislative changes, those related to economic conditions and those which are exogenous. In addition, they show that increases in taxes due to exogenous changes have a very restrictive effect (a $1 \%$ tax increase leads to a $3 \%$ decline in real GDP).

The seminal paper for fiscal policy SVAR approaches is Blanchard and Perotti (2002). They examined the effects of dynamic changes of government expenditures and taxes on GDP in the United States using the SVAR approach. Their results indicate that positive tax shocks have a negative effect on output and positive government spending shocks have a positive effect. However, the multipliers for both spending and tax shocks are small. The spending multiplier is close to one (0.9) while the tax multiplier is around 0,7 .

Other studies were conducted using econometric models. O.Biau and E.Girard (2004) draws on Blanchard and Perotti's (2002) SVAR approach to evaluate the effectiveness of fiscal policy in France over the period 1978-2003. Their paper shows that increase in public spending in France stimulates consumption and investment. On the other hand, the estimated impact on the activity of an increase in public revenue is negative, mainly because of the contraction of private consumption. However, the fiscal multiplier is small, near -0.1 , and is only significant in the very short term.

Christiano and al. (2010) studied, using a DSGE model, the issue of the multiplier of public spending in an open economy with a fixed nominal interest rate. These authors concluded that the value of the Government spending multiplier is generally greater than 1 . They also found that the effect of the public spending multiplier is more important when the nominal interest rate is constant.

As for Furceri, D. and A. Mourougane (2010), they examined the effects of fiscal policy on the activity in the euro area. By using a DSGE model with endogenous government bond yields, the authors demonstrated that fiscal policy can stimulate the activity, especially in the short term. They showed also that the most important fiscal multipliers are associated with an increase in public investment and public consumption as well as a decrease of the tax rate on wages.

In the same vein, Frédéric J. (2016), studied the short-term effects of public spending shocks in Morocco using the SVAR model, inspired by Blanchard and Perotti's (2002) identification approach. They quantify the size of the fiscal multiplier using impulse response functions. The main macroeconomic variables used are the government consumption, the real effective exchange rates, the trade balance to GDP ratio and the real GDP. The findings suggest that a government consumption shock has a weak impact on most macroeconomic variables, particularly real GDP. A positive government consumption shock increases real GDP by less than $0.005 \%$, while the estimated cumulative multiplier is around 0,6 . The author also pointed out the existence of strong correlations between real variables in the long term. However, the fiscal multipliers display a low persistence in the very short term.

The next section will briefly describe the SVAR approach used to examine the impact of fiscal policy shocks on 
economic activity in Morocco.

\section{The Structural VAR Approach}

This section provides the estimation of an SVAR model to assess the effects of fiscal policy. It first focuses on the SVAR methodology and in then on the identification approach of Blanchard and Perotti (2002), to finally expose the empirical results for the case of the Morocco.

\subsection{The Model}

The estimation of an SVAR model can solve a system of constraints reflecting the economic behavior, which helps with the economic interpretation of the identified structural shocks. The structural representation of a VAR model is:

$$
X_{t}=G_{1} X_{t-1}+\cdots+G_{P} X_{1-p}+u_{t}
$$

Where $u_{t}=A^{-1} B e_{t}$

Thus, the residuals of the reduced VAR model $u_{t}(\mathrm{n}, 1)$ are linear combinations of the structural shocks innovations of the vector $e_{t}=\left[e^{g}, e^{y}, e^{\pi}, e^{\tau}, e^{r}\right]$. Therefore, the specification of the matrix A and B enables to identify the structural shocks.

According to Perotti (2002), the reduced form of innovations of government spending $u_{t}^{g}$ and tax revenues $u_{t}^{\tau}$ are considered to be a linear combination of three components: instant automatic stabilizers and systematic discretionary measures and instant structural shocks.

\subsection{Identification of Restrictions}

The next step is to identify the restrictions to implement in matrices A and B which binds the structural innovations to the residuals of the reduced form.

The relation between structural shocks and reduced form shocks $u_{t}=A^{-1} B e_{t}$ can be rewritten as $u_{t}=B e_{t}$, and in the matrix form as:

$$
\left[\begin{array}{ccccc}
1 & 0 & 0,5 & 0 & 0 \\
-\propto_{y g} & 1 & 0 & -\propto_{y \tau} & 0 \\
-\propto_{\pi g} & -\propto_{\pi y} & 1 & -\propto_{\pi \tau} & 0 \\
0 & -0.9 & -1 & 1 & 0 \\
-\propto_{r g} & -\propto_{r y} & -\propto_{r \pi} & -\propto_{r \tau} & 1
\end{array}\right]\left[\begin{array}{c}
u_{t}^{g} \\
u_{t}^{y} \\
u_{t}^{\pi} \\
u_{t}^{\tau} \\
u_{t}^{r}
\end{array}\right]=\left[\begin{array}{ccccc}
\beta_{g g} & 0 & 0 & 0 & 0 \\
0 & \beta_{y y} & 0 & 0 & 0 \\
0 & 0 & \beta_{\pi \pi} & 0 & 0 \\
\beta_{\tau g} & 0 & 0 & \beta_{\tau \tau} & 0 \\
0 & 0 & 0 & 0 & \beta_{r r}
\end{array}\right]\left[\begin{array}{c}
e_{t}^{g} \\
e_{t}^{y} \\
e_{t}^{\pi} \\
e_{t}^{\tau} \\
e_{t}^{r}
\end{array}\right]
$$

This identification scheme relies first on the identification of the impact of inflation on the public spending, which is assumed to be equal to -0.5 (Caldara and Kamps, 2008). In fact, the wages are an important part of public charges which do not react instantly to the evolution of inflation. Which imply that an unexpected increase in inflation causes a decrease in personal spending.

Moreover, we assume that the elasticity of public spending to GDP $\propto_{g y}$ is equal to 0, presuming that the decision related to government spending does not depend on a future change in GDP. It is also assumed that inflation is not affected instantly by GDP.

Then, we adjust public spending and tax revenues to obtain an automatic response of these variables to the business cycle and inflation. This involves an estimation of the output elasticity of government revenue $\alpha_{\tau y}$ and the inflation elasticity of government revenue $\propto_{\tau \pi}$. These elasticities are calibrated to 0.9 and 1 .

In addition, we assume that $u_{t}^{r}$ do not influence instantly the other variables, which argues that the impact of a change in the interest rate requires a delay of transmission in order to affect the macroeconomic aggregates.

The next step, we suppose that the relationship between government spending and tax revenues is not instantaneous, which implies that $\propto_{\tau g}=0$. And by regressing public expenditures on tax revenues, we estimate the coefficient $\beta_{\text {tg }}=0.73$.

The final step determines the ordering of fiscal shocks. To do so, we set the parameter $\beta_{g \tau}=0$, assuming that government spending decisions are made before income decisions. Perotti (2002) presumes that the results are not sensitive to the ordering of fiscal shocks.

\subsection{Data}

The data used for estimation are annual data over the period $1980-2016$. The macroeconomic variables used in this analysis include government expenditure, real output, inflation rate, taxes and short-term interest rate for interest rate variable. The time series are drawn from High Commission for Planning and the General Treasury of the Kingdom and Bank al-Maghrib websites. All variables are used in logarithm except inflation. 
The Augmented Dickey-Fuller test shows that there is a unit root in the level of government expenditure, real output and taxes series. This indicates that these variables are not stationary and should be used in levels of first differences. Based on the selection criteria (Akaike Information Criterion) we estimated a vector autoregressive model with 2 lags.

\subsubsection{The Response to Public Spending Shock}

This figure summarizes the response to public expenditure shock according to the Blanchard and Perotti (2002) approach.

GDP

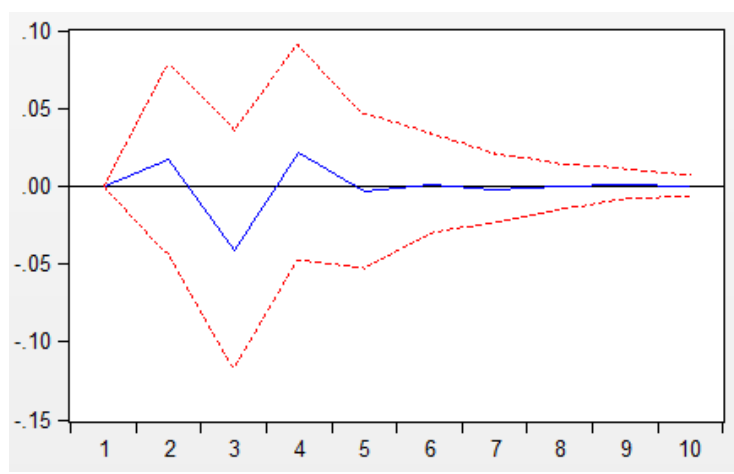

Inflation

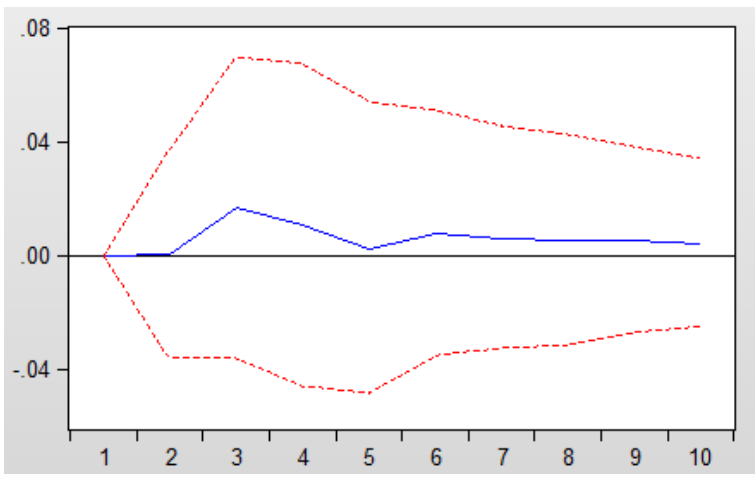

Taxe revenues

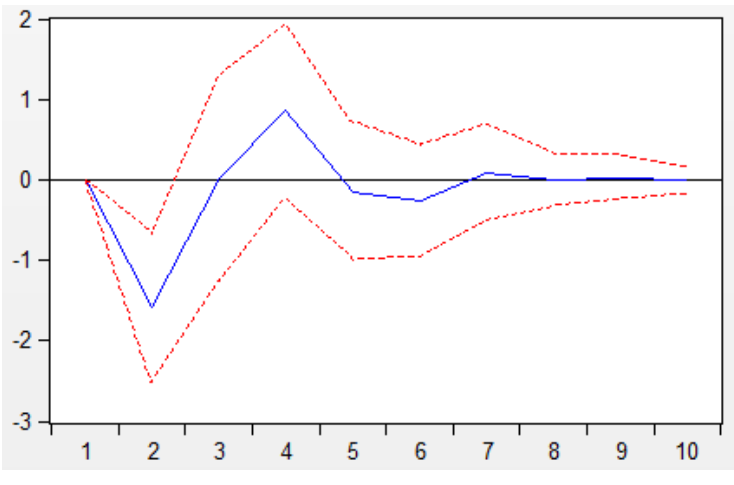

Interest rate

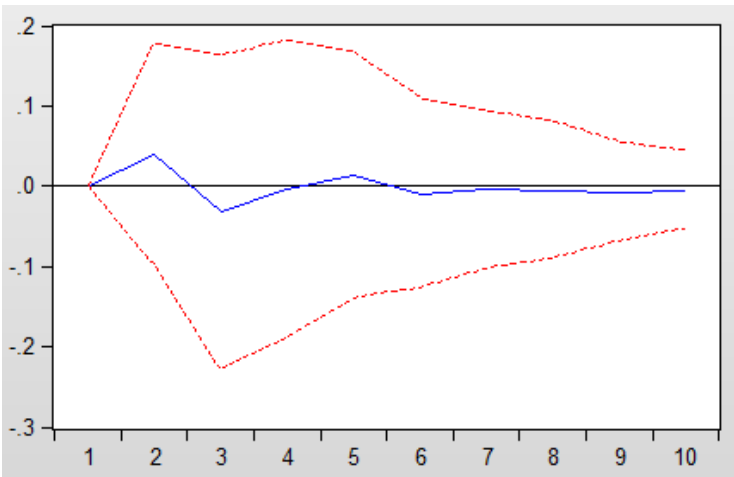

Figure 1. Response to Nonfactorized One S.D. Innovations \pm 2 S.E.

The results suggest that a public expenditure shock has a small impact on most macroeconomic variables, especially on real GDP, as it is shown in similar studies about emergent economies. A positive shock of public consumption increases real GDP by less than $0.05 \%$. The effect on real output fades gradually to become insignificant after five years. This evolution could be explained by the significant increase of prices. Public spending has also a positive effect on the interest rate, which can be interpreted as a response to the stimulation of the economic activity. The dynamic of inflation and interest rate after a government spending shocks is consistent with the economic theory. 


\subsubsection{The Response of Tax Revenues Shock}

The figure 2 summarizes the response of endogenous variables tax revenues shock.

GDP

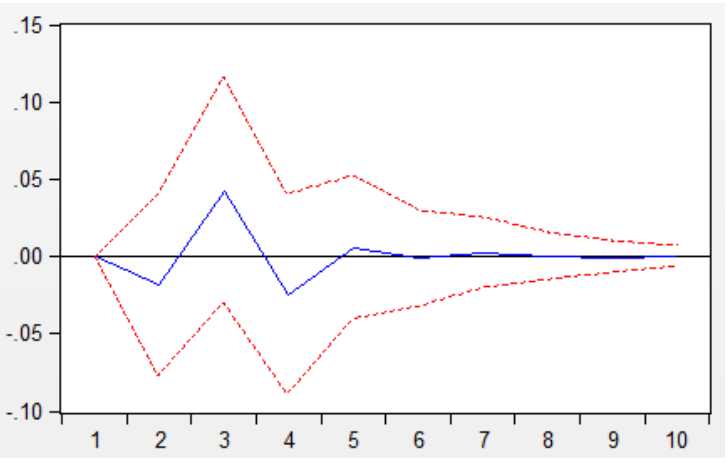

Inflation

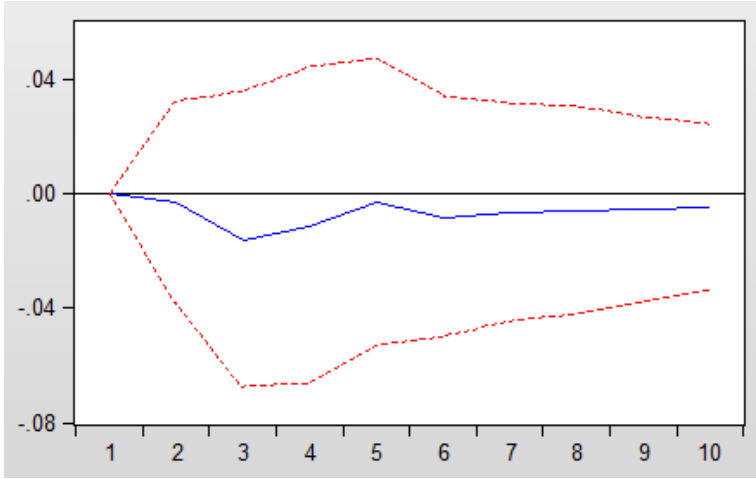

Public spending

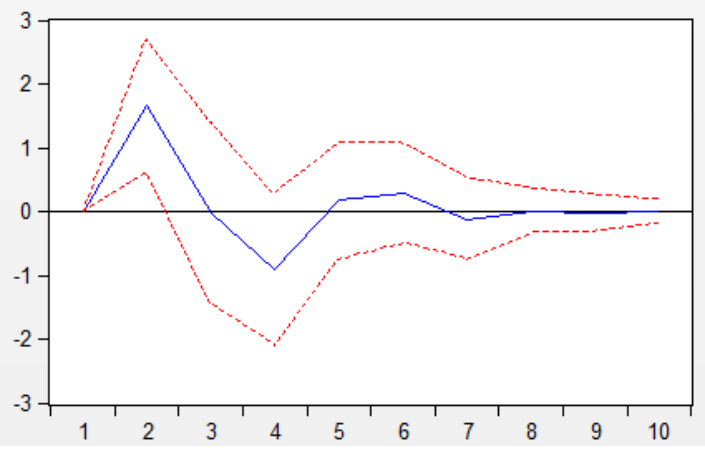

Interest rates

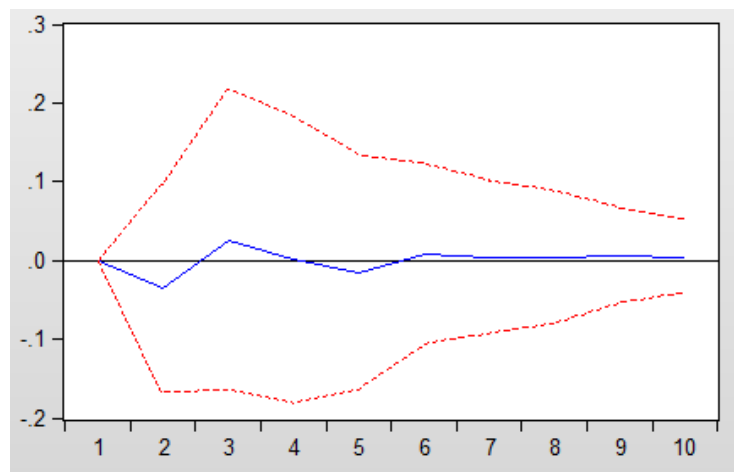

Figure 2. Response to Nonfactorized One S.D. Innovations \pm 2 S.E.

The response of real GDP to a tax revenue shock is low. The tax multiplier is $-0,003$. The effect on real output fads gradually after five years. The interest rate and the price index react both significantly negatively to tax revenues shock. Their low multipliers are consistent with the weak response of the activity.

\section{Conclusion}

This paper estimate the effect of fiscal policy shocks using Blanchard and Perotti approach. According to the impulse response functions, the public expenditure multiplier is positive and small meaning that the economic activity is not significantly influenced by public spending shocks. A small increase of the interest rate is also observed and can be interpreted as a response of monetary authorities to the minor stimulation of the activity. The results indicate also that tax revues shock has a weaker impact on economic activity. The interest rate and the price index react negatively to the tax revenue shock, with very low multipliers in harmony with the weak response of the activity. Moreover, the effect of fiscal policy is short lived since it dies completely after five years. The findings are consistent with the economic literature and empirical studies related to emergent countries. However, the assessment of fiscal policy shocks in morocco should be developed by evaluating fiscal policy effects on GDP components and investigating models designed to include more economic information.

\section{References}

Biau, O., \& Girard, E. (2004). Politique budgétaire et dynamique économique en France : l'approche var structurel. Economie \& prévision 2005/3 ( $\mathrm{n}^{\circ}$ 169-170-171), 1-23. https://www.afse.fr/global/gene/link.php?doc_id=66\&fg=1

Blanchard, O., \& Perotti, R. (2002). An Empirical Characterization of the Dynamic Effects of Changes in Government Spending and Taxes on Output. Quarterly Journal of Economics, 117(4), 1329-1368. https://doi.org/10.1162/003355302320935043

Caldara D., \& Kamps, C. (2008). What are the effects of fiscal policy shocks? A var-based comparative analysis. $\begin{array}{lllll}\text { European Central } & \text { Bank, working } & \text { paper } & \text { series } & n^{\circ} 877 \text {. }\end{array}$ https://www.ecb.europa.eu/pub/pdf/scpwps/ecbwp877.pdf?b671fdff757ed5d1da6cd7104d694ea6

Christina, D. R., \& David, H. R. (2007). The Macroeconomic Effects of Tax Changes: Estimates Based on a New Measure of Fiscal Shocks. NBER Working Papers 13264. http://www.nber.org/papers/w13264 
Cristiano, \& al. (2010). Financial factors in economic fluctuations, European Central Bank, working paper series n 1192 . http://www.ecb.europa.eu/pub/pdf/scpwps/ecbwp1192.pdf

De Castro, F. (2003). The macroeconomic effects of fiscal policy in Spain. Bank of Spain, Studies Unit, paper work $\mathrm{n}^{\circ} 0311$.

http://www.bde.es/f/webbde/SES/Secciones/Publicaciones/PublicacionesSeriadas/DocumentosTrabajo/03/Fic/dt03 11e.pdf

Frédéric, J., \& al (2016), Morocco- Selected issues, International Monetary Fund. https://www.imf.org/external/pubs/ft/scr/2016/cr1636.pdf

Furceri, D., \& Mourougane, A. (2010) The Effects of Fiscal Policy on Output. A DSGE analysis, OECD Economics Department, Working Papers, No. 770, OECD Publishing, Paris. https://doi.org/10.1787/5kmfp4z3njg0-en

Ilzetzki, E., \& Carlos, A. V. (2009). Procyclical Fiscal Policy in Developing Countries: Truth or Fiction? NBER Working Papers 14191. https://doi.org/10.3386/w14191

Ramey, V. A., \& Shapiro, M. (1998). Costly Capital Reallocation and the Effects of Government Spending. Carnegie Rochester Conference on Public Policy, pages 145-194. https://doi.org/10.1016/S0167-2231(98)00020-7

Uhlig, H. (2005). What Are the Exects of Monetary Policy on Output? Results from an Agnostic Identification Procedure. Journal of Monetary Economics, 52, 381-419. https://doi.org/10.1016/j.jmoneco.2004.05.007

\section{Copyrights}

Copyright for this article is retained by the author(s), with first publication rights granted to the journal.

This is an open-access article distributed under the terms and conditions of the Creative Commons Attribution license which permits unrestricted use, distribution, and reproduction in any medium, provided the original work is properly cited. 